\title{
The thermoelectric generators use for waste heat utilization from cement plant
}

\author{
Karol Sztekler ${ }^{1,}$, Krzysztof Wojciechowski ${ }^{2}$, Maciej Komorowski ${ }^{1}$, Milena Tarnowska ${ }^{1}$ \\ ${ }^{1}$ AGH University, Faculty of Energy and Fuels, Mickiewicza Av. 30, 30-059 Krakow, Poland \\ ${ }^{2}$ AGH University, Faculty of Materials Science and Ceramics, Mickiewicza Av. 30, 30-059 Krakow, \\ Poland
}

\begin{abstract}
Nowadays, one of the major economic problems is the increasing energy consumption and the long-term forecasts electricity demand by 2050 will increase several times as compared to 1990 . Hence also to reduce the emissions of harmful combustion products there are investments undertaken for inter alia renewable energy sources and seeks to make the most efficient manufacturing system by levelling eg. heat losses at various stages of production, eg. electricity or also another product.

Production often entails the formation of by-product which is waste heat. One of the equipment processing heat into electricity is a thermoelectric generator. Its operation is based on the principle of thermoelectric phenomenon, which is known as a Seebeck phenomenon. The simplicity of thermoelectric phenomena allows its use in various industries, in which the main waste product is in the form of heat with the temperature of several hundred degrees. The study analyses the possibility of the thermoelectric systems use for the waste heat utilization resulting in the cement production at the cement plant. The location and design of the thermoelectric system that could be implemented in cement plant is chosen. The analysis has been prepared in the IPSEpro software.
\end{abstract}

\section{Introduction}

The cement industry in Poland, in terms of production volume is on seventh place among the European cement producers. Deep technical modernisation, which took place in the industry in the last decade, caused the industry in terms of technology is at the European and world forefront. 13 cement plants operating in the country is one of the most modern in Europe. These plants in the past few years have been modernised at the cost of 10 billion PLN. The cement industry in Poland directly and indirectly employs more than 24,000 people. In 2013, cement sales in Poland amounted to 14.3 million tonnes and was lower by 8\% compared to the 2012 year. The 2014 annual sale of cement in Poland was close to the level of 15.2 million tons.

Favourable trend continued in 2015, when cement sales amounted to approximately 16.4 million tons $[9,11]$. Cement plant average consumes approx. 4 GJ energy to produce 1

\footnotetext{
* Corresponding author: sztekler@agh.edu.pl
} 
tonne of cement (in China up to $5.4 \mathrm{GJ} / \mathrm{t}$ ) $[2,3,4,6]$. In table 1 , the energy consumption (heat and electricity) for various types of rotary kilns used in the cement industry is presented.

Table. 1. Energy consumption for different methods of clinker in rotary kilns [6]

\begin{tabular}{|c|c|c|}
\hline Methods production cement & Heat energy [GJ/t] & Electricity [MWh/t] \\
\hline wet method furnaces long & $5,0-7,5$ & 0,025 \\
\hline half wet method - furnaces long / Lepol & $3,4-4,0$ & 0,03 \\
\hline half dry method - furnaces long / Lepol & $3-3,9$ & 0,03 \\
\hline dry method - furnaces with precalciner & $3,1-3,2$ & 0,022 \\
\hline shaft furnaces & $3,7-6,6$ & 0,03 \\
\hline
\end{tabular}

Based on the gathered information, it can be concluded that the cement industry due to high consumption of heat and electricity (which transfer into $\mathrm{CO}_{2}$ emissions) and emissions associated with the clinker production process adversely affect environment and all actions aimed at improvement of cement production efficiency will benefit to reduce energy consumption and reduce emissions of harmful gases into the atmosphere. The aim of this study is to present possible directions of waste heat utilisation in the cement plant with a strong focus on the use of thermoelectric generators for the utilisation of waste heat from rotary kilns. Calculations were made for the rotary kiln installed in Rudniki cement plant and the results of the analysis will help to show the potential use of thermoelectric generators in large scale industry $[2,3,4]$.

\section{Reduction of the cement plant negative impact on the environment}

The cement industry is a highly energy-intensive and high consumption of raw materials and natural non-renewable fuels, joined the realisation of the policy of effective management of raw materials and energy, in line with the policy of sustainable development leads to: Increase in the production of the share of renewable and alternative energy sources; Promote energy efficiency; Reducing the negative impact of manufacturing processes and use of fuel and energy to the environment; Improvement (further development) of production processes; Valorisation of wastes in production processes; Replacement of fuels with a high content of $\mathrm{C}$ element with less $\mathrm{C}$ element fuels (eg. switching from coal to gas); The capture of carbon dioxide from the flue gases; Reduce the amount of carbon dioxide emitted by vehicles $[4,5]$. Emission of carbon dioxide from the cement industry accounts for about $5 \%$ of global emissions resulting from human activity. In Poland in 2002 year the emissions from the cement industry was around 7,824 thousand tons, equivalent to the emissions per unit of approximately $0.69 \mathrm{~kg} /$ tonne of produced cement [4]. Manufacturing of 1 ton of clinker is accompanied by 0.5 tonnes of emitted technology $\mathrm{CO}_{2}$. Over $50 \%$ of the total emissions from the cement industry is technology $\mathrm{CO}_{2}[2,3,4,6]$. There are several methods reducing the amount of carbon dioxide emitted per tonne of produced cement until 2020 year [6] for example: change electricity production (Increasing the efficiency of energy production and electricity from the fuels with low carbon content) -reduction carbon dioxide less than 5\%; use of alternative fuels in cement production process- reduction carbon dioxide less than 5\%; emission from the transport (change the type of fuel)- reduction carbon dioxide less than $20 \%$. Despite a significant reduction in carbon dioxide emissions (in Poland, the amount of emitted carbon dioxide per unit of clinker decreased of about $40 \%$ compared to the beginning 
of the nineties of the last century), cement industry carries out activities aimed at further reducing its emissions. Another way to reduce the negative impacts on the environment in the cement industry is the use of waste energy. Even approx. $15 \%$ of the waste energy can be recovered in the cement plant through the use of appropriate technical solutions which are discussed below [8]. The overall efficiency of the manufacturing process of cement clinker with dry process in rotary kiln is approx. 50\%. Some rotary kilns operating at full power declare the efficiency of approx. 55\%. The use of heat recovery can apparently increase the efficiency of rotary kilns which will help to reduce the consumption of fuel, energy and $\mathrm{CO}_{2}$ emissions. Manufacture of the clinker in the rotary kiln is the most energy intensive step in the cement production process (consumes approx. $90 \%$ of the total heat energy consumption). While to produce each tonne of cement an average of $90-130 \mathrm{kWh}$ of electricity is consumed. The share of energy costs in the form of fuel and electricity is on average about $50 \%$ of the total costs associated with the production of one tonne of cement $[4,5]$. As is apparent from (Fig. 1) the thermal balance of modern rotary kiln on the dry method shown in the Sanke graph, it is energy intensive process with an efficiency of 50\%. Significant, more than $40 \%$, the impact of the high energy consumption of the clinker burning process in a rotary kiln have heat losses: In the exhaust gases; With excess air of the clinker cooler grate; Radiation and convection of hot surfaces and rotary kilns. The enthalpy of the exhaust gases from the rotary kiln and the enthalpy of excess air from the clinker cooler is about $30 \%$ of the heat losses of the clinker burning process. In the Fig. 1 the sources of waste energy from the rotary kiln and possible ways of its use are shown. Till now common in the cement industry process of waste heat use (particular enthalpy of flue gases and excess air) is to use it for raw materials, coal and slag drying. Therefore, it is advisable to search for new technologies for waste heat utilisation (production of electricity) which might arise from the exhaust gases and radiant heat of the rotary kiln. Therefore, the electricity generation in a cement plant from waste heat from the rotary kiln can be achieved by: Classic steam cycle (Clausius-Rankine cycle); An organic Rankine cycle (ORC); Kalina cycle; Installation of a steam engine block. Practically all of these methods originate from the classic ClausiusaRankine cycle. Both ORC and Kalina cycles have found practical use in the cement industry. Modern installations of electricity generation, so-called WHR (Waste Heat Recovery) are used in the cement industry.
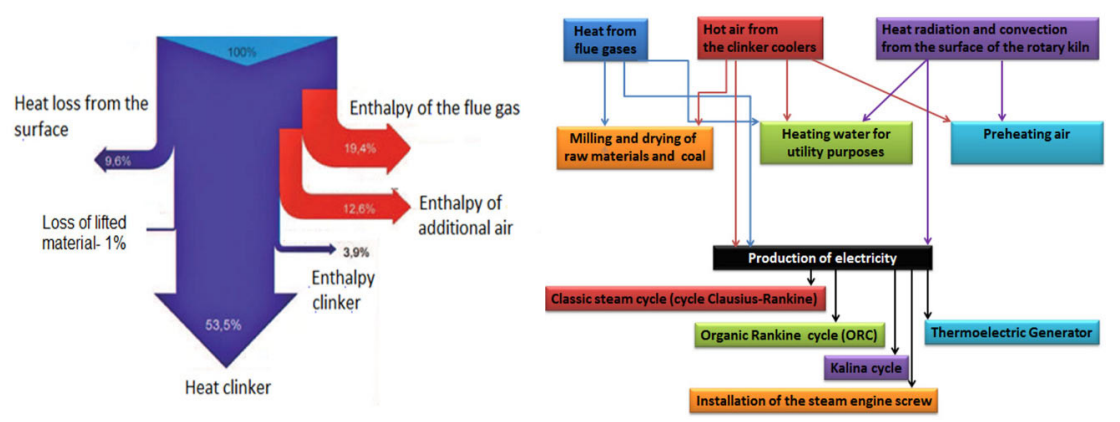

Fig. 1. Heat balance of cement kiln and possibility of heat utilization [5]

A global leader in the implementation of WHR cogeneration systems in the cement industry is the Japanese company Kawasaki Heavy Industries (KHI), which in 1980 in the Sumitomo Osaka Cement Plant has built and launched the first WHR installation. But already in 1982, KHI launched Taiheiyo Cement plant with an electrical capacity of $15 \mathrm{MW}$, securing more than $30 \%$ of the electric power demand by the cement plant. In recent years, to 2009 Kawasaki company launched 106 such plants with a total electric capacity of $1413 \mathrm{MW}$. The 
average energy recovery in new cogeneration systems in cement plants is approx. 30-45 $\mathrm{kWh} / \mathrm{Mg}$ cement $[5,7,8]$.

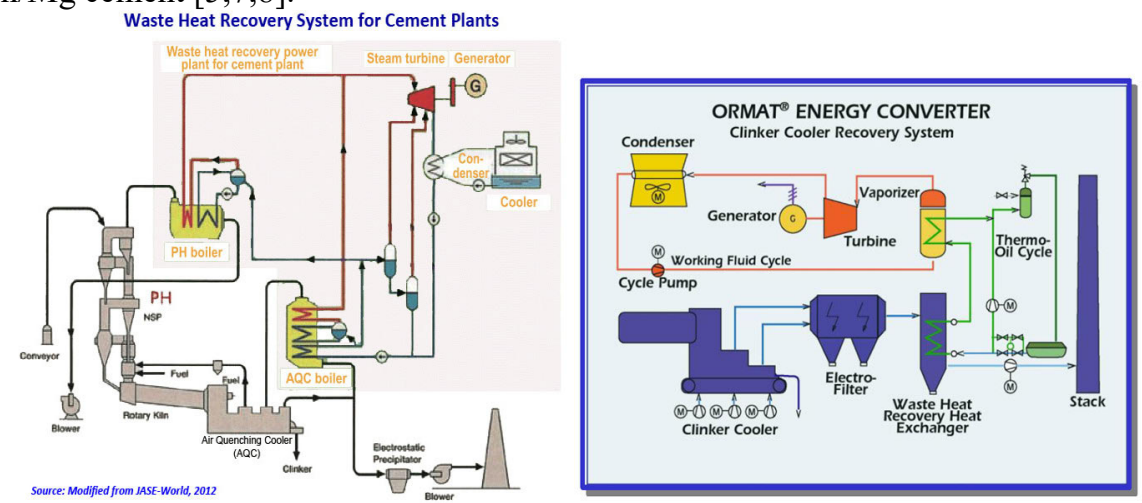

Fig.2. Electricity production from waste heat a) steam cycle; b) ORC cycle [12]

Accordingly, the duplication of world WHR solutions based on a classical Rankine cycle is very limited for offered terms. This causes a relatively low temperature of the flue gases derived from the rotary kiln (approx. $620 \mathrm{~K}$ ), high enthalpy variation of excess air from the coolers (large temperature fluctuations) and the required heat in the drying process of fuel and other products require a different technology than the classic Rankine way generating electricity from the waste enthalpy. In Poland, in practice the implementation of WHR technology is limited to the two techniques - ORC and Kalina cycle. In 2010-12-08 - The Swiss company Holcim increased the efficiency of their cement plant because in Untervaz use of ABB modern heat recovery system based on ORC cycle. Such solution may be implemented in many cement plants in Poland $[12,6]$. Another possible technical solution for the utilisation of waste heat emitted by radiation from the rotary kiln shell is the use of the thermoelectric generator and the direct electricity production. Device transforming heat into electricity is a thermoelectric generator. Its operation is based on the principle of thermoelectric phenomenon, a phenomenon known as the Seebeck effect. Seebeck Effect (Fig .3) depends on the formation of electromotive force in a circuit consisting of two conductors connected to the two ends of which the contacts are located at different temperatures is thus possible to convert thermal energy into electricity, an essential element of executing this process is a thermocouple. For the system to work with an assumed efficiency suitable large temperature difference between the hot and cold side is required. Hence thermoelectric generator is nothing else like a heat exchanger, which in addition to electricity production can produce hot water for utility purposes or any other medium used for the thermoelectric generator cooling. The investigations were conducted at the AGH University of Science and Technology.

The tested system (Fig. 3) in optimal conditions generate a power of $200 \mathrm{~W}$, acting with efficiency in the range of 1.1-1.9\%. Maximum efficiency of thermoelectric modules was amounted to $3 \%$. At the AGH Laboratory thermoelectric modules were developed that can be used at higher temperatures. Their highest possible efficiency is $9 \%$. This type of solution is based on thermoelectric generators is examined in this article [1]. 

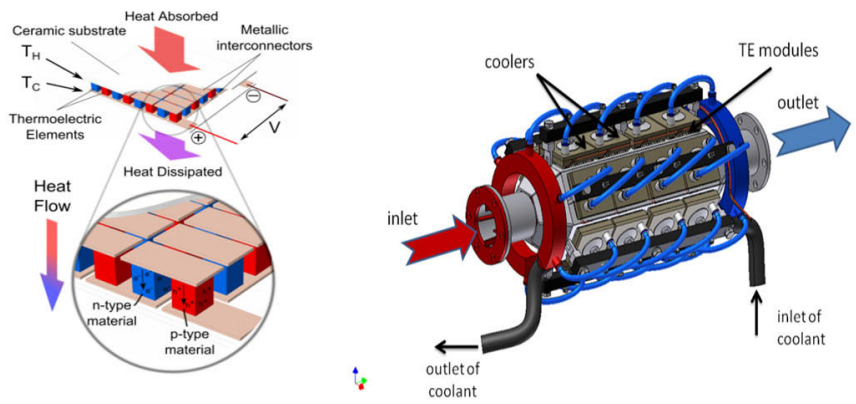

Fig.3. Thermoelectric generator a) The principle of thermoelectric generator b) thermoelectric generator prototype made by AGH [1]

\section{Waste heat utilisation from the rotary kiln in Rudniki Cement Plant}

Rudniki Cement Plant near Czestochowa is engaged in production: cements (slag, mixed or composite, limestone, steel), road binders (from the year 2009) and limestone. In Rudniki annual production capacity of cement is $1200 \mathrm{kt}$, while the clinker is $650 \mathrm{kt}$. [10,13]. Currently in the Rudniki Cement Plant are 2 ways of waste heat utilisation which is emitted by the rotary kiln installation. In 2009 is run pipeline of the hot gases received from the furnace, which are used for drying of the raw material fed to the raw meal preparation in two ball mills. In 2014 it was built another second pipeline of exhaust gases supplied to the coal department, where they are used for coal drying in a ball mill. There is no heat recovery from the rotary kilns radiation in cement plant $[10,13]$.

\subsection{Design assumptions}

Hot surface of the rotary kiln, which can reach temperatures of over $400{ }^{\circ} \mathrm{C}$ is another significant source of heat loss. Convection and radiation losses may constitute approx. 8-15\% of the energy input. Rotary kilns by radiation emit considerable amounts of heat that may be used by thermoelectric generator to produce electricity and heat (in the form of hot water and for heating of the cement plant buildings) The heat dissipated by the rotary kiln is done by radiation and convection. However, in the zone of the highest temperature heat transfer is dominated by radiation (approx. 4 times higher coefficient of heat transfer by radiation than convective coefficient) [14]. Thus, in the paper it is contemplated the use of thermoelectric generator operating as a radiation heat exchanger for a rotary kiln no. 4. Diagram of the system operation for waste heat utilisation from the rotary kiln is presented in Fig no.4. Thermoelectric generator (TEG) must be placed in the zone of the rotary kiln no. 4, where is the highest temperature. In the section of 16-28 m initial length of the cement kiln, where there was on a selected range of Ar 1 maximum temperature of $348.7{ }^{\circ} \mathrm{C}$, this part of the furnace was considered as a potential place to install thermoelectric generator. In view of the operational and technological considerations exchanger must not obstruct the operation, repair work or maintenance, so it is expected to placement in suitable distance from the rotary kiln. Distance of thermoelectric generator to the cement kiln should be as small as possible, but the above reasons, considering the application of the mechanism governing this distance. Most preferred would be to place the heat exchanger enclosing the rotary kiln in figure 4 , but for the reasons of TEG implementing it will be located under the furnace and the generator is formed as a cylinder surface comprising a sixth circuit of the rotary kiln, which 
is a solid angle of $60^{\circ}$ within a distance of $1 \mathrm{~m}$ from the furnace, provided with a frame on wheels, which can be easily moved.

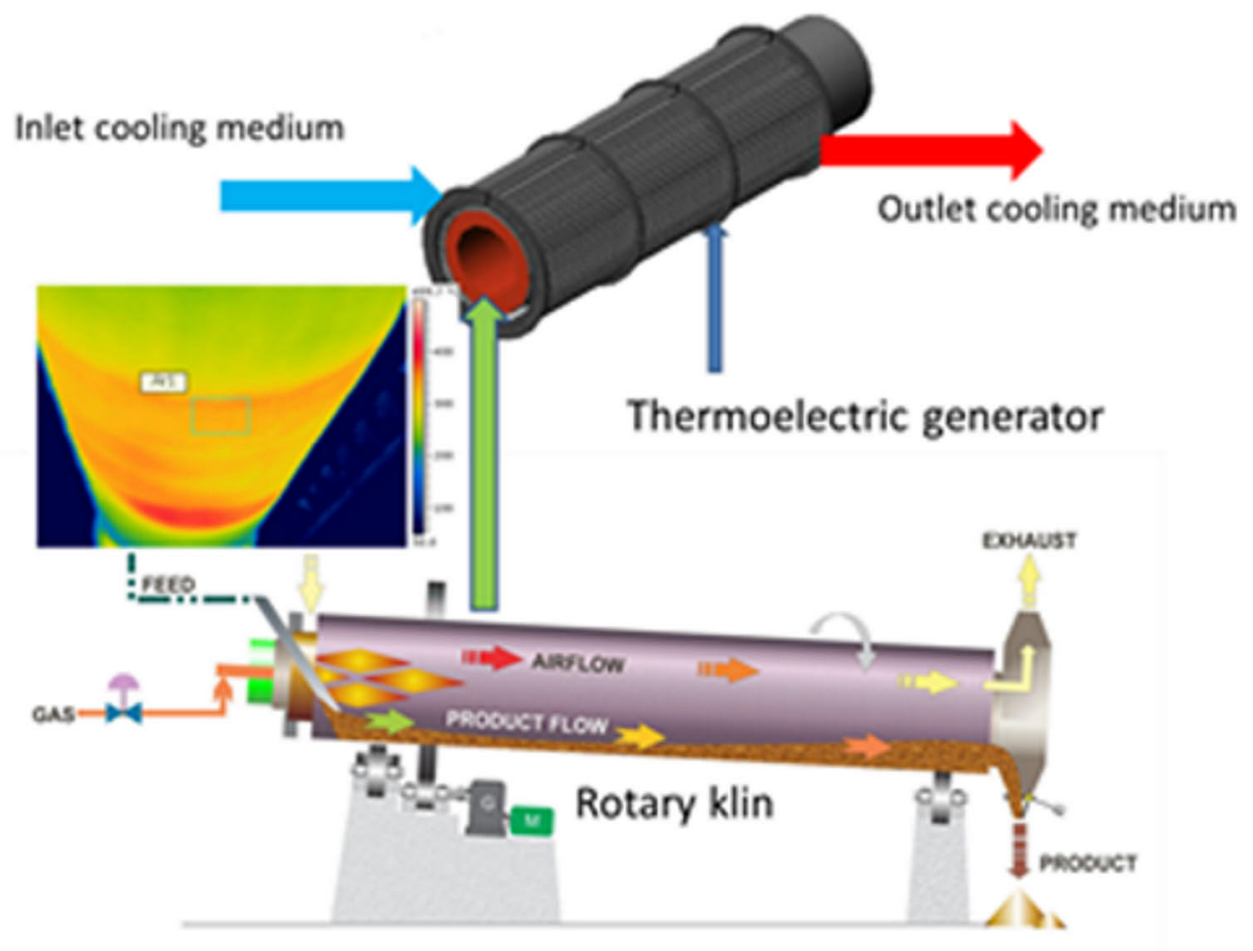

Fig.4. Schem instalation thermelectic generation in rotary klin

In addition, it can be in the area of the furnace throat, wherein the diameter is changed from $3.75 \mathrm{~m}$ to $3.45 \mathrm{~m}$, in areas where supports are provided, and where run frequently used road transport. Other assumptions for the calculation: averaged temperature of the rotary kiln shell in section $16-28 \mathrm{~m}: \mathrm{t}_{1}=316{ }^{\circ} \mathrm{C}$; the length of the exchanger installation $\mathrm{l}_{1}=12 \mathrm{~m}$; for the cooling of the thermoelectric generator is used the water at input temperature of $12{ }^{\circ} \mathrm{C}$ and output temperature of $65^{\circ} \mathrm{C}$; Calculations are performed for the temperature $\mathrm{T}_{2}$ of the wall surface of the thermoelectric generator (TEG) in the range of 37.6 to $40.5{ }^{\circ} \mathrm{C}$; efficiency of electricity generation using the thermoelectric generator in this temperature range is assumed to be $7 \%$, based on the literature [1].

For the thermal - flow calculation of the thermoelectric generator heat exchanger should be designated [14]:

The configuration factor

$$
\varphi_{1-2}=\frac{1}{A_{1}} \int_{A_{1}} \int_{A_{2}} \frac{\cos \varphi_{1} \cos \varphi_{2}}{\pi r^{2}} d A_{1} d A_{2}
$$

$\mathrm{A}_{1}$ - surface discharge heat (rotary klin) $\left[\mathrm{m}^{2}\right]$

$\mathrm{A}_{2}$ - area of absorbing heat (thermoelectric generator) $\left[\mathrm{m}^{2}\right]$

$\varphi_{1}$ - configuration factor for surface discharge heat

$\varphi_{2}$ - configuration factor for surfaces absorbing heat

$\mathrm{r}$ - the distance between the furnace and the heat exchanger the thermoelectric generator $[\mathrm{m}]$ 
- Calculation of heat flux absorbed by the TEG (thermoelectric generator) walls from the rotary kiln

$$
q_{1-2}=\varepsilon_{1} \cdot \varepsilon_{2} \cdot \varphi_{c} \cdot C_{0}\left[\left(\frac{T_{1}}{100}\right)^{4}-\left(\frac{T_{2}}{100}\right)^{4}\right]\left[\frac{W}{m^{2}}\right]
$$

$\varepsilon_{1}-$ emissivity of the surface area of the furnace

$\varepsilon_{2}-$ emissivity of the surface of steel pipes

$\mathrm{C}_{0}-$ technical constant radiation of a black body $\left[\mathrm{W} \cdot \mathrm{K}^{4} / \mathrm{m}^{2}\right]$

$\mathrm{T}_{1}$ - temperature surface rotary kiln $[\mathrm{K}]$

$\mathrm{T}_{2}$ - temperature surface thermoelectric generator $[\mathrm{K}]$

- Calculation of the thermal power absorbed by the TEG [28]

$$
Q_{1-2}=q_{1-2} \cdot \pi \cdot d_{z} \cdot L[W](3)
$$

$\mathrm{L}$ - the length of the pipe in the thermoelectric generator $[\mathrm{m}]$

- Calculation of water flow velocity in the TEG tubes

$$
\begin{gathered}
v=\frac{Q_{1-2}}{\frac{\pi \cdot d_{w}^{2}}{4} \cdot \rho \cdot c_{p} \cdot \Delta t_{f}}\left[\frac{m}{s}\right] \\
\Delta t_{f}=t_{w y}-t_{w e}
\end{gathered}
$$

$\mathrm{t}_{\mathrm{we}}$ - inlet temperature of the cooling water TEG $\left[{ }^{0} \mathrm{C}\right]$

$\mathrm{t}_{\mathrm{wy}}$ - outlet temperature of the cooling water TEG $\left[{ }^{\circ} \mathrm{C}\right]$

$\rho-$ density of water $\left[\mathrm{kg} / \mathrm{m}^{3}\right]$

$\mathrm{C}_{\mathrm{p}}$ - specific heat at $\mathrm{p}=$ const $[\mathrm{J} /(\mathrm{kg} \cdot \mathrm{K})]$

$\mathrm{d}_{\mathrm{w}}, \mathrm{d}_{\mathrm{z}}$-inner/ outer diameter pipe in the thermoelectric generator [m]

- Calculation of the Reynolds number

$$
\operatorname{Re}=\frac{v \cdot d_{w}}{v_{f}}
$$

$v$ - kinematic viscosity $\left[\mathrm{m}^{2} / \mathrm{s}\right]$

$v_{\mathrm{f}}-$ kinematic viscosity of water at a reference temperature $\left[\mathrm{m}^{2} / \mathrm{s}\right]$

- Calculation of Prandtl number for water at reference temperature $t_{\mathrm{fm}}$ and the wall temperature $\mathrm{t}_{2}$

$$
\operatorname{Pr}=-3,379 \ln (t)+17(6)
$$

- Calculation of heat transfer coefficient

$\lambda$ - thermal conductivity $[\mathrm{W} /(\mathrm{m} \cdot \mathrm{K})]$

$$
\alpha=\frac{N u \cdot \lambda}{d_{w}}\left[\frac{W}{m^{2} \cdot K}\right](7)
$$

$\mathrm{Nu}$ - Nusselt number 
Used Michiejew correlation for Nusselt number, depending on the type of flow

- laminar flow:

$$
\mathrm{Nu}=0,15 \cdot R e^{0,33} \cdot P r_{f m}{ }^{0,43} \cdot G r^{0,1}\left(\frac{P r_{f m}}{P r_{2}}\right)^{0,25} \cdot \varepsilon_{L}(8)
$$

Prfm - Prandtl number for reference parameters

Pr2- Prandtl number for surfaces absorbing heat

- Calculation of heat flux acquired by the exchanger tubes of the rotary kiln

$$
q_{2-1}=\alpha\left(t_{2}-t_{f m}\right)\left[\frac{W}{m^{2}}\right](9)
$$

$\mathrm{t}_{\mathrm{fm}}$ - reference temperature, $\mathrm{t}_{\mathrm{fm}}=37.5^{\circ} \mathrm{C}$

$\alpha$ - heat transfer coefficient $\left[\mathrm{W} /\left(\mathrm{m}^{2} \mathrm{~K}\right)\right]$

\section{Calculation results and conclusions}

The results of the calculations for the TEG with a length of $12 \mathrm{~m}$ at a distance from the rotary kiln $\mathrm{s}=1-4 \mathrm{~m}$ have been summarised in the table. Below, the calculation for the interval $\mathrm{L}=12 \mathrm{~m}(16-28 \mathrm{~m})$ are at different distances from the furnace shell, wherein the shell is the average temperature $\mathrm{t}_{1}=316^{\circ} \mathrm{C}$.

Table 2. Results of the calculations for the TEG installed on rotary kiln

\begin{tabular}{|c|c|c|c|c|c|c|c|c|c|c|c|}
\hline $\mathbf{S}$ & $\mathbf{t}_{\mathbf{2}}$ & $\boldsymbol{\varphi}_{\mathbf{c}}$ & $\mathbf{q}_{1-2}$ & $\mathbf{Q}_{1-2}$ & $\mathbf{P}_{\text {elTEG }}$ & $\mathbf{v}$ & $\mathbf{R e}$ & $\begin{array}{c}\mathbf{P r}_{2} \\
\mathbf{f o r} \mathbf{t}_{\mathbf{2}}\end{array}$ & $\mathbf{N u}$ & $\boldsymbol{\alpha}$ & $\mathbf{q}_{\mathbf{2}-1}$ \\
\hline $\mathbf{m}$ & ${ }^{\circ} \mathbf{C}$ & - & $\mathbf{W} / \mathbf{m}^{2}$ & $\mathbf{k W}$ & $\mathbf{K W}$ & $\mathbf{m} / \mathbf{s}$ & - & - & - & $\mathbf{W} /\left(\mathbf{m}^{2} \mathbf{K}\right)$ & $\mathbf{W} / \mathbf{m}^{2}$ \\
\hline 1 & 39.4 & 1.38 & 4232.6 & 163.34 & 11.43 & 0.459 & 29782 & 4.59 & 157.19 & 2199.22 & 4178.52 \\
\hline 1.4 & 39.2 & 0.802 & 2460.48 & 94.95 & 6.65 & 0.267 & 17313 & 4.6 & 101.75 & 1423.62 & 2420.15 \\
\hline 1.8 & 39.1 & 0.544 & 1670.42 & 64.46 & 4.51 & 0.181 & 11754 & 4.61 & 74.61 & 1043.84 & 1670.14 \\
\hline 2.2 & 39.1 & 0.404 & 1239.92 & 47.85 & 3.35 & 0.134 & 8725 & 4.61 & 56.2 & 786.29 & 1258.06 \\
\hline 2.6 & 39.1 & 0.318 & 975 & 37.63 & 2.63 & 0.106 & 6861 & 4.62 & 45.23 & 632.81 & 949.22 \\
\hline 3 & 39.1 & 0.26 & 797.71 & 30.78 & 2.15 & 0.086 & 5613 & 4.61 & 36.39 & 509.16 & 814.65 \\
\hline 3.4 & 39.1 & 0.219 & 672.01 & 25.93 & 1.82 & 0.073 & 4729 & 4.61 & 29.37 & 410.89 & 657.43 \\
\hline 3.8 & 39.2 & 0.189 & 578.71 & 22.33 & 1.56 & 0.063 & 4072 & 4.6 & 23.77 & 332.59 & 565.4 \\
\hline 4 & 39.3 & 0.176 & 540.64 & 20.86 & 1.46 & 0.059 & 3804 & 4.6 & 21.4 & 299.35 & 538.84 \\
\hline
\end{tabular}


For the case under consideration the use thermoelectric generator for waste heat utilisation emitted from the surface of the rotary kiln in the radiation path is proposed. This paper proposes a thermoelectric generator with a length of $12 \mathrm{~m}$ located on the length of 16$28 \mathrm{~m}$ of no. 4 rotary kiln. The rotary kiln will not be completely built with thermoelectric generator in this section, but it will be placed under the furnace in the form of cylinder surface covering $1 / 6$ of the circumference of the rotary kiln, which is the solid angle $60^{\circ}$. It will receive heat from approx. $1.35 \%$ of the area of the side of the furnace. TEG can produce from $\mathrm{P}_{\text {elTEG }}=1.46 \mathrm{kWe}$ to about $\mathrm{P}_{\text {elTEG }}=11 \mathrm{kWe}$ of electricity which translates to receive by radiation of Q1-2=10kWth to Q1-2 = $163 \mathrm{~kW}$ th depending on the distance to the surface of the TEG furnace. The highest achieved power TEG is possible at a generator distance of $1 \mathrm{~m}$ from the rotary kiln surface. Since the essence of the action TEG receives heat from the hot side, this allows for production of hot water for hot water and heating plant. With the TEG with a maximum power of approx. $163 \mathrm{kWth}$ and $11 \mathrm{kWe}$ Cement Plant reaches saving of burned fuel. The plant will be able to afford to completely disable the boiler room in summer (May-September), while in winter there will be aided working exchanger. A very important element is to equip TEG in the continuous measurement of the temperature of input and output water, which will give an indication to the approximation, or the distance from the kiln shell heat exchanger depending on the current needs of the Plant for hot tap water. In addition, heat has no influence on the quality of the final material produced in the Plant and the whole technological process.

The article was funded from government money Faculty of Energy and Fuels number 11.11.210.216 and Faculty of Materials Science and Ceramics number 11.11.160.438

\section{References}

1. K. Wojciechowski, J. Merkisz, P. Fuć, J. Tmankiewicz, R. Zybała, J. Leszczyński, P. Lijewski, P. Nieroda, Prototypical thermoelectric generator for waste heat conversion from combustion engines Combustion Engines ; ISSN 0138-0346. — R. 52 nr 3 (2013)

2. A. Uliasz Bocheńczyk A., E. Mokrzycki, Emisja dwutlenku węgla w przemyśle cementowym. Polityka Energetyczna, tom 20, zeszyt 2, s. 129-143 (2003)

3. B. Vanderborght, B. Brodmann, The Cement CO2 Protocol: CO2 Emissions Monitoring and Reporting Protocol for the Cement Industry. Guide to the Protocol, version 1.6 www.wbcsdcement.org (2001)

4. A. Uliasz Bocheńczyk A., E. Mokrzycki, Możliwości ograniczenia emisji CO2 w przemyśle cementowym. Polityka energetyczna Tom 7 Zeszyt specjalny Wyd. Instytut GSMiE PAN Kraków s. 555-564 PL ISSN 1429.6675 (2004)

5. A. Duczkowska -Kądziel A., J. Duda, Methods of increasing the electric power generated from waste heat in association with a rotary kiln,. Heat Transfer and Renewable Sources of Energy HTRSE-2012

6. E. Worell, L. Price, N. Martin, Ch. Hendriks, M.L. Ozawa, Carbon dioxide emission from cement industry. Annual Review of Energy and the Environment,26, pp. 303-329 (2001)

7. J. Duda, K. JesionekJ, Zagospodarowanie procesowego ciepła odpadowego na przykładzie Cementowni. „Prace Naukowe”, Politechnika Warszawska, Warszawa, s. 47-53 (2011)

8. J. H a r d e r, Trends in power generation from waste heat in cement plants, ,ZementKalk-Gips" s. 36-47 (2011)

9. .http://www.polskicement.pl/aktualnosci/W_2015_roku_wzrost_sprzedazy_cementu_w Polsce_do_16_mln_ton-308

10. $\bar{C}$ ementownia Rudniki. Dostępny: http://www.cemex.pl/cementownia-rudniki.aspx 
11. http://www.polskicement.pl/files/Pages/225/uploaded/informator\%202014\%20$\% 204 \% 20$ strony\%20-\%20low.pdf

12. H. Legmann, ORMAT Industries, Recovery of industrial heat in the cement industry by means of the ORC process. papers\IEEE 2002\4066|July 11, 2002

13. Tarnowska M., Projekt wymiennika do odzysku ciepła wydzielanego przez piece obrotowe" Praca dyplomowa, 2016

14. Poniewski M., Orzechowski T., Cesarz Cz., Chajewski R., Gołaszewski K., Lubowicz M., et al.: Utylizacja ciepła odpadowego cz. II, Zlec. nr 1839/13, Kielce, Politechnika Świętokrzyska, Samodzielny Zakład Termodynamiki i Mechaniki Płynów, 1993 